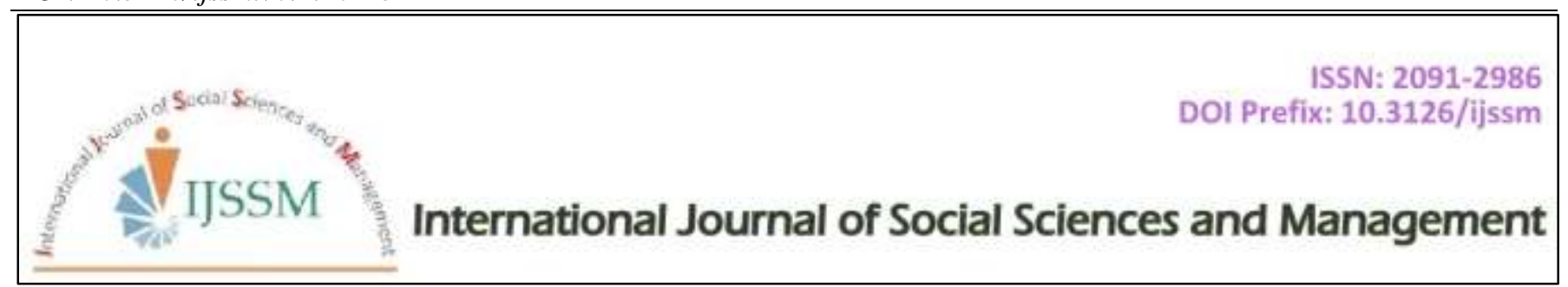

Research Article

\title{
Commercialization of Mandarin Orange in Solukhumbu District, Nepal: Input, Production, Storage and Marketing Problem Assessment
}

\author{
Kamal Nayan Pant ${ }^{1 *}$, Dikshit Poudel ${ }^{1}$, Dipendra Kumar Bamma ${ }^{1}$, Shovit Khanal ${ }^{1}$, Madhav \\ Dhital $^{1}$
}

Agriculture and Forestry University, Nepal

\begin{abstract}
With the aim to assess major constraints and opportunities in commercialization along with the study of control measures and apposite services provided by stakeholders, the survey among 75 households from 5 different clusters in major citrus producing Dudhkoshi and Thulung Dudhkoshi regions during 2018 was conducted. The result from the pilot study portrays that - despite the long-term farming experiences in citrus, mandarins were unproductive in their orchards. Lack of technical knowledge, input supply, road and market access regarding commercial citrus farming has been major limiting aspect for orchard management and production. Likewise, condition of mechanical tools and record keeping was found poor from direct observation. 49.33\% did not have storage facility for the fruit; problem on post-harvest and marketing was followed by poor transportation facility. The market for mandarin was the local market for 34 respondents where the price per kg was NRs. 77.94 which was significantly higher than the farmgate price (NRs. 49.02) at $5 \%$ level of significance. The fruit has invincible quality and taste. The development of collection centers, frequent monitoring and trainings for progressive farmers and input supplies management from government and private sectors are suggested, which can promote the productivity of citrus; thus, farming of mandarin can enhance livelihood and can be sustainable venture for the study area.
\end{abstract}

Keywords: mandarins; constraints; inputs; production; commercialization

\section{Introduction}

Citrus occupies about $32 \%$ of the total area under fruit production in Nepal (MoAD, Statistic Agriculture Book, 2016). In Agriculture Perspective Plan (1995-2015), it was placed under high-value crops. For development and commercialization of citrus, Government of Nepal is continuously conducting various programs such as citrus area extension, lemon mission, and Orange-Mandarin pocket area extension. But due to lack of use of modern tools and technology and prolonged domination of traditional farming system, commercialization in citrus farming has not been achieved (Pun, 2015).

Solukhumbu is a district located on the Himalayan ecological belt in the northeast. The geographical diversity of the district presents the variability in the climatic conditions prevailing in the district. The climatic condition and the edaphic factor in the southern slope of the mid-hill region are suitable for Citrus production in the district. 20

\section{Cite this article as:}

K.N. Pant et al. (2019) Int. J. Soc. Sc. Manage. Vol. 6, Issue-4: 97-104. DOI: 10.3126/ijssm.v6i4.26223

$1 *$ Corresponding author

Kamal Nayan Pant,

Agriculture and Forestry University, Nepal

Email: kamalpant266@gmail.com

Peer reviewed under authority of IJSSM

(C) 2019 International Journal of Social Sciences and Management

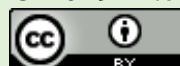

This is an open access article \& it is licensed under a Creative Commons Attribution 4.0 International License (https://creativecommons.org/licenses/by/4.0/) 
out of 31 VDC in the district produce Citrus with $1148 \mathrm{Mt}$ production and $7.06 \mathrm{Mt} /$ ha productivity (DADO, 2016). The major Agricultural organizations working on the district include District Agriculture Development Office, Horticulture Centre: Phaplu, PMAMP- Zone (Citrus) Implementation Unit, High Mountain Agribusiness and Livelihood Improvement Project (HIMALI) Project, EcoHimal Project, Agriculture Service Centre. The PMAP-PIU is working with the mission of productivity enhancement, agricultural mechanization and commercialization in Mandarin Subsector(MoAD, Project Document of Prime Minister Agriculture Modernization Project, 2017). The national productivity of Citrus is $11.03 \mathrm{Mt} \mathrm{ha}^{-1}$ that is 35.99 $\%$ higher than that of Solukhumbu district showcasing the effect of disease pest, unhealthy seedling, management practices and other factors on citrus production (DADO, 2016; NCRP, 2016). The major problems regarding the commercialization and intensive farming of citrus include lack of proper technology adoption, poor and inefficient irrigation practices, lack of fertilization, low yielder varieties, poor nursery management and orchard establishment practices, effect of disease and pests, improper harvesting practices, lack of collection, storage, transportation and marketing facilities (Gelal, 2018).
Along with traditional practice of cultivation, many other factors are responsible for the low production and commercialization of citrus. The study aims to assess the key issues and the loopholes across all three steps of the value chain: production, marketing and middle actors that link production with the markets. This study also assesses all the pre-harvest and post-harvest factors which are causing hindrance in the commercial farming of citrus in this region. Furthermore, the pilot study will help to prioritize the strengths, weakness, opportunity and threats in commercial citrus farming along with exploration of the control measures adopted by the farmers for mitigation of the problems.

\section{Methodology}

\section{Study Site}

The research was conducted in the project area of PMAMPPIU. Dudhkoshi RMP 4,5(Kanku) and Thulung Dudhkoshi RMP 6,7 \& 8(Mukli and Deusa) were purposively selected for the research to achieve the aforementioned objectives. The main criteria for selecting these places were due to the fact that these places have the potential for commercial citrus farming having fertile soil, suitable topography, and road accessibility (Fig. 1).

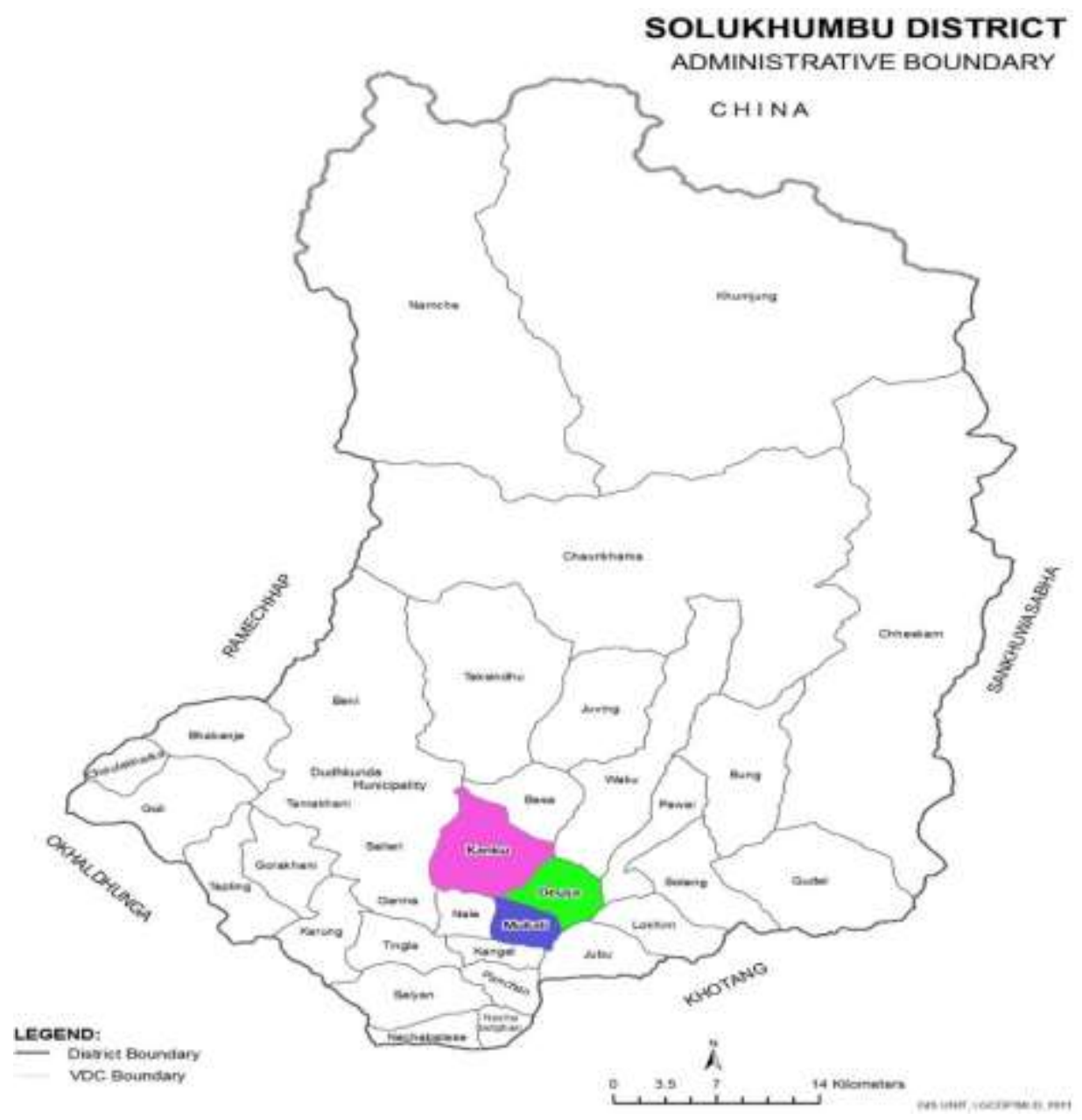

Fig. 1: Map showing study area 
Thulung Dudhkosi RMP 7 and 8 (Deusa) had the highest area (61 ha) under citrus production which ranked first in production (495 Mt) followed by Dudhkoshi 4 and 5 $(K a n k u)$ with 18.6 ha area under citrus production having production of $130 \mathrm{Mt}$. Thulung Dudhkoshi 6 had relatively less area under citrus cultivation than other two areas (5.66 ha) and production $(30 \mathrm{Mt})$. In the past three years Deusa produced the highest amount of citrus but with a negligible increase in productivity from 8.1 Mt/ha in FY 2069/70 to 8.11 Mt/ha in FY 2072/73. However, in Kanku and Mukli the productivity was in decreasing trend over the past three years. In Kanku productivity decreased from $8 \mathrm{Mt} / \mathrm{ha}$ in FY $2069 / 70$ to $6.99 \mathrm{Mt} / \mathrm{ha}$ in FY 2072/73. Similarly, in Mukli productivity decreased from $7.77 \mathrm{Mt} / \mathrm{ha}$ in FY 2069/70 to 5.33 Mt/ha in FY 2072/73. In the project area, the area under citrus cultivation was very low when compared to the total cultivable area. The major ethnic group in the area were Rai, Dalits, Chhetri, and Newar.

\section{Respondent Selection}

At first, sampling frame was prepared by including the citrus growing farmers of Thulung Dudhkoshi RMP 6, 7 \& 8(Deusa and Mukli) and Dudhkoshi RMP 4 \& 5(Kanku) using various sources of information such as key informants of the study areas, district profile of DADO, village profile prepared by PIU and Rural Municipalities. Farmers were selected after consulting the previous data about citrus production in the project area published by the rural municipality, DADO, and PMAMP-PIU (Solukhumbu). The farmers who were growing citrus in at least 3 ropani were taken as the sampling unit. Seventy-five commercial citrus growers of the selected VDCs were selected for the study through simple random sampling.

\section{Data and Their Sources}

The commercial farmer of Deusa, Mukli, and Kanku were the major sources of the primary data and data were collected through a semi-structured questionnaire applying face to face interviews technique. Apart from these, the information was obtained through observation, informal group discussion, and key informant survey was also given due consideration. The secondary data were collected from the articles, reports, books that were published by different institutes and organizations.

\section{Data Analysis}

The completion of the survey was followed by the processing and analysis of data. First, the information collected from the field entered into computer followed by coding and tabulation. Simple statistical analytical tools were used for data analysis. Data were analyzed by using Statistical Package for Social Science (SPSS) and Microsoft Excel Software package (MS-Excel).

\section{Result and Discussion}

In this section, major findings of the research after the analysis of collected Statistical information are discussed and interpreted. Results are discussed by using statistical and scientific tools and techniques along with previous supportive research findings in the citrus commodity. The findings of the study are as follows:

\section{Socioeconomic Information}

Majority of the respondent population were male (72\%) in the present study. This is due to the fact that most of the male were involved in economic activities and females were restricted to household works. The number of an economically active population dominated the respondent population i.e. $15-59$ age group $(62.7 \%)$. About $76 \%$ of the population were educated while $24 \%$ were illiterate.

Among the respondent population having agriculture as the main source of income $(62.67 \%)$, only $27.65 \%$ rely in obtaining annual income.

Average years of experience of citrus farmers in the area were 16.55 years with minimum 3 years and maximum 45 years. From the data, it can be explained that farmers were involved in citrus farming fora long period.

\section{Problems in Citrus Farming}

Major problems in commercial citrus farming are categorized as input, production, post-harvest,and marketing problems. For prioritizing the problems in different conditions the problems are further categorized as technical, managerial \& socioeconomic problems. Indexing, frequency table, andweightage table are used for prioritization of the problem.

\section{Problems in The Input-Supply}

\section{Technical Problems}

Data shown in Table 1 shows the unavailability of mechanical tools occupied highest rank (3.97) being main problem in input followed by the unavailability of suitable variety (3.65) and unavailability of grafted plants with trifoliate (3.27).

From the Table 1, it can also be explained that the problem having high frequency of most severity (5) which was the unavailability of mechanical tools (20) has affected farmers most seriously and the problem with the high frequency of least severity (1) which was the unavailability of planting materials had the lowest effect in farming. However, the data in the table showed that suitable plant variety and grafted plants with trifoliate were not available as required. So it can be concluded that planting materials are available to farmers but the high yielding variety and planting materials grafted with trifoliate were not easily available.

\section{Management and Socio-Economic Problems}

According to the index value, low power to purchase input material ranked as major problem followed by lack of coordination and linkage between sellers-market actors and lack of subsidy from co-operatives. From this data, it can be concluded that majority of the farmers were economically 
poor and don't have the ability to purchase the quality planting material, fertilizers, irrigation infrastructures, pesticides and mechanical tools required for citrus farming. Similarly, farmers didn't have access to the market for purchasing mechanical tools, fertilizers, and pesticides, as well as they, didn't have any linkage and co-operation with market actors and sellers. However, some farmers in the area responded that lack of subsidy from co-operatives and organizations in agri-inputs was their major problem. Some farmers in the area had poor co-ordination among them for collective effort in purchasing inputs (Table 2).

Average income of farmers of the area was lower than national line of poverty i.e. average income of the area is below 1.25 USD per day which is the reason behind their low purchasing capacity.

\section{Problems in Production}

\section{Technical Problems}

The data shown in Table 3 shows insect pest attack has the highest index value $(0.92)$ which is near to 1 which means it was the most severe problem in the production of citrus followed by lack of irrigation and lack of training-pruning.

In the area, insect and disease had high incidence which were major cause for pre-harvest and post-harvest loss of fruit. Irrigation was another serious problem as stated by farmers which directly affects the vegetative growth, fruit set,and development. Lack of training \& pruning for proper management of orchard was another problem as stated by respondent farmers. Most of the respondents used farmyard manure for fertilization. The poor practice of fertilization in the area was other bad package of practice adopted for citrus.

Table 1: Prioritization of technical problems in input

\begin{tabular}{|c|c|c|c|c|c|c|c|c|}
\hline \multirow[t]{2}{*}{ Technical Problems } & \multicolumn{5}{|c|}{ Weightage } & \multirow{2}{*}{$\begin{array}{l}\text { Total } \\
\text { Weightage }\end{array}$} & \multirow[t]{2}{*}{ Mean } & \multirow[t]{2}{*}{ Rank } \\
\hline & 1 & 2 & 3 & 4 & 5 & & & \\
\hline Unavailability of Mechanical Tools & $1(1)$ & $8(4)$ & $33(11)$ & $156(39)$ & $100(20)$ & 298 & 3.97 & $\mathrm{I}$ \\
\hline $\begin{array}{l}\text { Unavailability of Variety with high } \\
\text { productivity }\end{array}$ & $1(1)$ & $16(8)$ & $72(24)$ & $100(25)$ & $85(17)$ & 274 & 3.65 & II \\
\hline $\begin{array}{l}\text { Unavailability of Grafted Plant } \\
\text { with Trifoliate }\end{array}$ & $3(3)$ & $16(8)$ & $99(33)$ & $112(28)$ & $15(3)$ & 245 & 3.27 & III \\
\hline Lack of Nursery Raising Structure & $7(7)$ & $16(8)$ & $84(28)$ & $112(28)$ & $20(4)$ & 239 & 3.19 & IV \\
\hline Unavailability of Planting Materials & $16(16)$ & $70(35)$ & $57(19)$ & $16(4)$ & $5(1)$ & 164 & 2.19 & $\mathrm{~V}$ \\
\hline
\end{tabular}

Number in parenthesis indicate frequency

Table 2: Prioritization of management and socio-economic problems

\begin{tabular}{|l|l|l|l|l|l|l|l|l|}
\hline Management and Socio-economic Problems & \multicolumn{3}{|c|}{ Weightage } & \multirow{2}{*}{ Weight } & \multirow{2}{*}{ Index } & Rank \\
\cline { 2 - 10 } & $\mathbf{1}$ & $\mathbf{0 . 8 0}$ & $\mathbf{0 . 6}$ & $\mathbf{0 . 4}$ & $\mathbf{0 . 2}$ & & & \\
\hline Low purchasing capacity & 52 & 3 & 20 & 0 & 0 & 66.4 & 0.89 & I \\
\hline Market Linkage and Co-operation & 20 & 36 & 12 & 6 & 1 & 58.6 & 0.78 & II \\
\hline Lack of subsidy from Co-operatives & 2 & 45 & 25 & 2 & 1 & 54 & 0.72 & III \\
\hline Lack of knowledge on inputs & 1 & 4 & 4 & 47 & 19 & 29.2 & 0.39 & IV \\
\hline Co-ordination among local community & 0 & 0 & 1 & 20 & 54 & 19.4 & 0.26 & V \\
\hline
\end{tabular}

Table 3: Prioritization of technical problems in production

\begin{tabular}{|l|r|r|r|r|r|r|r|r|}
\hline \multirow{2}{*}{ Technical Problems } & \multicolumn{3}{|c|}{ Weightage } & \multirow{2}{*}{ Weight } & \multirow{2}{*}{ Index } & Rank \\
\cline { 2 - 10 } & $\mathbf{1}$ & $\mathbf{0 . 8}$ & $\mathbf{0 . 6}$ & $\mathbf{0 . 4}$ & $\mathbf{0 . 2}$ & & & \\
\hline Insect pest attack & 49 & 23 & 2 & 1 & 0 & 69 & 0.92 & I \\
\hline Lack of irrigation & 10 & 22 & 25 & 8 & 10 & 47.8 & 0.64 & II \\
\hline Lack of training and pruning & 8 & 12 & 20 & 20 & 15 & 40.6 & 0.54 & III \\
\hline Lack of fertilization & 6 & 11 & 20 & 5 & 42 & 37.2 & 0.50 & IV \\
\hline Poor soil and climatic conditions & 2 & 7 & 8 & 41 & 17 & 32.2 & 0.43 & V \\
\hline
\end{tabular}




\section{Major insect pests of citrus in the study area}

Some of the major diseases and insect pests are tabulated below to find out the most serious problem among them.

\section{Major diseases of citrus in the study area}

The Table 4 depicts powdery mildew was the most serious disease of the citrus growers followed by fruit drop and root rot. The present finding is supported by the findings of Poudel (2016) conducted in the same area.

\section{Major insects of citrus in the study area}

Fruit fly was reported as the major problem of the orchard followed by ant and stem parasites (Table 5).

\section{Control Measures in Practice}

Farmers were incognizant regarding control measures against diseases and insects. However, citrus zone office provided farmers with lime, blue vitriol for bordeaux paste and mixture preparation and chemical agents like neemarin, copper oxychloride and pheromone traps along with training to use them (Table 6).

Total of 16 famers were reported using cow urine spray, applying dung, spraying ash and tobacco with satisfactory result. Bordeaux mixture was somehow more satisfactory for eradication of pests. Though adopted by 10 farmers, Use of chemical agents was reported more successful.

Table 4: Indexing of major diseases in the citrus orchards

\begin{tabular}{|l|c|c|c|c|c|c|c|c|}
\hline \multirow{2}{*}{ Disease } & \multicolumn{5}{|c|}{ Weightage } & \multirow{2}{*}{ Weight } & Index & \multirow{2}{*}{ Rank } \\
\cline { 2 - 9 } & $\mathbf{1}$ & $\mathbf{0 . 8}$ & $\mathbf{0 . 6}$ & $\mathbf{0 . 4}$ & $\mathbf{0 . 2}$ & & & \\
\hline Powdery Mildew & 20 & 30 & 19 & 0 & 2 & 55.6 & 0.794286 & I \\
\hline Fruit Drop & 35 & 10 & 8 & 10 & 8 & 53.2 & 0.76 & II \\
\hline Root Rot & 10 & 15 & 20 & 15 & 11 & 42 & 0.6 & III \\
\hline Yellowing & 5 & 8 & 14 & 20 & 24 & 32.4 & 0.462857 & IV \\
\hline Wilting & 0 & 7 & 9 & 25 & 30 & 26.8 & 0.382857 & V \\
\hline
\end{tabular}

Table 5: Indexing of major insects in the citrus orchards

\begin{tabular}{|c|c|c|c|c|c|c|c|c|}
\hline \multirow{2}{*}{ Problem } & \multicolumn{5}{|c|}{ Weightage } & \multirow{2}{*}{ Weight } & \multirow{2}{*}{ Index } & \multirow{2}{*}{ Rank } \\
\hline & 1 & 0.8 & 0.6 & 0.4 & 0.2 & & & \\
\hline Fruit Fly & 41 & 16 & 12 & 5 & 1 & 63.2 & 0.90 & I \\
\hline Ant & 11 & 16 & 18 & 18 & 11 & 44 & 0.63 & II \\
\hline Stem Parasites & 11 & 17 & 11 & 14 & 21 & 41 & 0.59 & III \\
\hline Aphid & 6 & 21 & 13 & 16 & 19 & 40.8 & 0.58 & IV \\
\hline Bug & 6 & 5 & 21 & 22 & 22 & 35.8 & 0.51 & $\mathrm{~V}$ \\
\hline
\end{tabular}

Table 6: Control measures used by farmers of the project area

\begin{tabular}{|l|l|l|}
\hline \multirow{2}{*}{ Control intervention practices } & Responses & \multirow{2}{*}{ Satisfaction level } \\
\cline { 2 - 3 } & N & \\
\hline \multirow{2}{*}{ Use of Bordo paste and mixture } & 19 & Highly satisfactory \\
\cline { 2 - 3 } & 19 & Satisfactory \\
\hline \multirow{3}{*}{ Regular training and pruning } & 1 & Highly satisfactory \\
\cline { 2 - 3 } & 34 & Satisfactory \\
\cline { 2 - 3 } & 23 & Not satisfactory \\
\hline \multirow{2}{*}{ Use of chemical agents } & 7 & Highly satisfactory \\
\cline { 2 - 3 } & 3 & Satisfactory \\
\hline Cow urine and dung & 12 & Satisfactory \\
\hline Applying ash and tobacco & 4 & Satisfactory \\
\hline
\end{tabular}




\section{Socio-Economic Problems}

The following Fig. 1 shows that out of 75 respondents 68 farmers didn't keep the record of their farm which is very essential for proper management of the enterprise. Natural calamities like hailstone and storm caused pre-harvest loss of the fruit according to 40 respondent farmers. As told by 15 out of 75 respondents foreign employment hampered in citrus farming. Active members of 7 households were involved in trekking as a major occupation which becomes another problem for citrus commercialization in the area and 5 farmers responded increasing permanent migration to Salleri and Kathmandu as a major problem for commercialization.

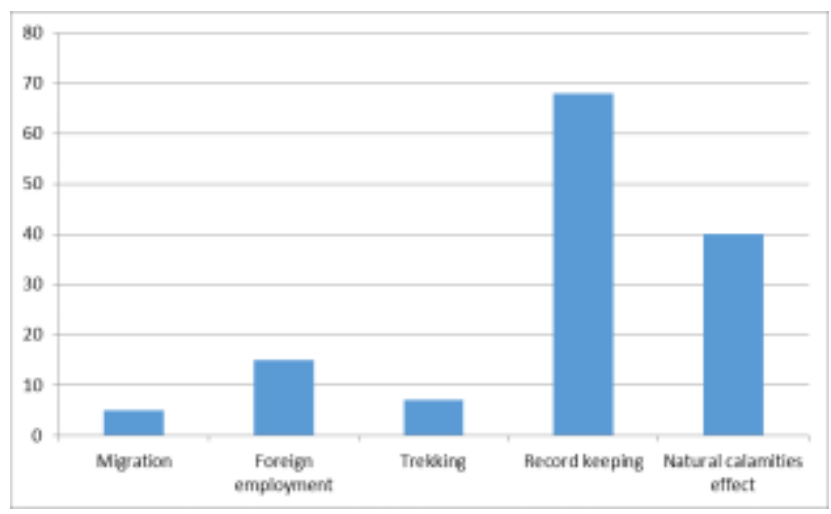

Fig. 1: Major management and socio-economic problems

\section{Effect of Natural Calamities}

Natural calamities caused preharvest loss in citrus orchards among 40 respondents.

The loss was recorded from $5 \mathrm{~kg}$ to $40 \mathrm{~kg}$ with an average loss of 14.96. This data shows that the ill effect of natural calamities is one of the major reasons for set fruit loss.

Most of the natural calamities affected the orchard in January to March. The main season for harvesting the mandarin is December to January in the study area but due to lack of market, poor market price, lack of storage, unavailability of collection house and contract farming they are forced to keep fruit unharvest until March; the time is prone to hailstone damage.

\section{Intercropping Practice in The Study Area and Comparison of B/C Ratio}

Some primary sources were assessed to obtain profitable intercropping practice. $35.7 \%$ of the farmers practice maizemillet intercropping with citrus which has lowest $\mathrm{B} / \mathrm{C}$ ratio (1.21). However, the farmers who were involved in legume intercropping had the highest $\mathrm{B} / \mathrm{C}$ ratio which indicates a high profit per ropani. In the data it was found that intercropping with maize, millet and coffee has low citrus production per plants as compared to others but those intercropped with legumes and chilly had high production per plant in the orchard. This was due to the ill effect of maize and coffee on citrus plants by competing for light, space, and nutrients. In contrast, legumes had beneficial effects on plants as they help in fixation of atmospheric nitrogen in the soil (Table 7).

Table 7: Intercropping in citrus and comparison of $\mathrm{B} / \mathrm{C}$ ratio among different practices

\begin{tabular}{|l|l|l|l|}
\hline S.N. & Intercropped plants & Percent & B/C Ratio \\
\hline 1 & None & 25.3 & 1.68 \\
\hline 2 & Maize-millet & 34.7 & 1.21 \\
\hline 4 & Coffee & 5.3 & 1.28 \\
\hline 5 & legumes & 12.0 & 1.80 \\
\hline 6 & Colocasia & 6.7 & 1.56 \\
\hline 7 & Chilly & 16.0 & 1.64 \\
\hline & Total & 100.0 & \\
\hline
\end{tabular}

$\mathrm{B} / \mathrm{C}$ ratio of 2.03 was recorded in Dhankuta and 2.08 in Ramechhap (Aryal and Bhandari, 2011). Lower B/C ratio in Solukhumbu was due to poor production technology and cultivation practices.

\section{Machineries Used in Production Process}

The Fig. 2 depicts the trend of using sickle and spade in the citrus orchard. This explains more traditional way of cultivation. Generally, these tools were not used for citrus farming which showed that they lack information regarding tools used in citrus cultivation. About half of the respondents used secateurs in the orchard while power tiller users were negligible. The tools and machineries used in the citrus orchard were provided by PMAMP-PIU with $50 \%$ subsidy.

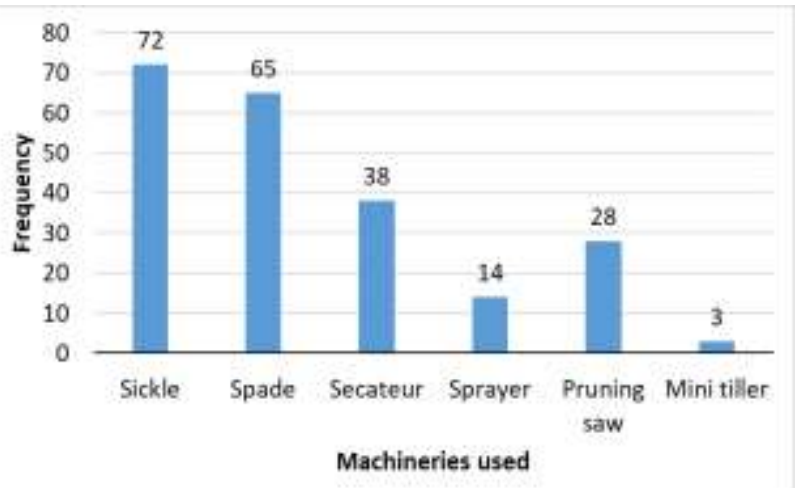

Fig. 2: Machineries used in the citrus orchard of the project area.

\section{Post-Harvest and Marketing Problems}

The responses portray poor transportation followed by unavailability of cellar storage and collection house and poor market pricing to be major postharvest and marketing problems in the study area (Table 8).

\section{Storage Mechanism of Harvested Fruit}

Among the respondents, $49.33 \%$ didn't store the fruit as they sell the fruit immediately after harvest. Other provisions 
like use of bamboo baskets (doko) and direct floor storage is being practiced. As we can see none of the respondents used cellar storage and cold store we can conclude that lack of storage facility is one of the major problems in the area (Table 9).

\section{Estimated Loss and The Main Reason for The Post- \\ Harvest Loss}

The data shown in Table 10 shows that mean loss after harvest is $15.22 \mathrm{~kg}$ per $100 \mathrm{~kg}$ of harvested fruit. Most of the producers faced poor transportation as the most serious problem which caused the highest loss of harvested fruit per $100 \mathrm{~kg}$ i.e. $17.11 \mathrm{~kg}$. The table shows other problems with respective losses.

\section{Value Addition Activities Performed}

Most of the respondents graded the fruits as large, medium and small but no standards were used by the farmers for grading. So the size among the same grade may be different from farmer to farmer. Only one respondent used packaging and about $37 \%$ didn't do any post-harvest activities (Table 11).

Table 8: Indexing of major post-harvest and marketing problems

\begin{tabular}{|l|r|r|r|r|r|r|r|r|r|r|}
\hline \multirow{2}{*}{ Problems } & \multicolumn{7}{|c|}{ Weightage } & & \\
\cline { 2 - 12 } & $\mathbf{1}$ & $\mathbf{0 . 8 6}$ & $\mathbf{0 . 7 1}$ & $\mathbf{0 . 5 7}$ & $\mathbf{0 . 4 3}$ & $\mathbf{0 . 2 9}$ & $\mathbf{0 . 1 4}$ & Weight & Index & Rank \\
\hline Poor transportation facility & 25 & 17 & 13 & 5 & 7 & 5 & 3 & 56.55 & 0.81 & I \\
\hline Unavailability of cellar storage & 15 & 20 & 10 & 13 & 4 & 6 & 7 & 51.12 & 0.73 & II \\
\hline Unavailability of Collection house & 10 & 12 & 11 & 8 & 18 & 7 & 9 & 43.68 & 0.62 & III \\
\hline Poor Market Price & 7 & 9 & 14 & 17 & 12 & 6 & 10 & 42.68 & 0.61 & IV \\
\hline Insect pest attack & 7 & 4 & 14 & 9 & 12 & 17 & 12 & 37.25 & 0.53 & V \\
\hline High interference of middleman & 6 & 7 & 5 & 12 & 13 & 19 & 13 & 35.25 & 0.50 & VI \\
\hline Product left unsold & 5 & 6 & 8 & 11 & 9 & 15 & 21 & 33.24 & 0.47 & VII \\
\hline
\end{tabular}

Table 9: Storage mechanism of harvested fruit

\begin{tabular}{|l|l|l|}
\hline Storage & Frequency & Percent \\
\hline On the floor & 23 & 30.67 \\
\hline Bamboo baskets & 15 & 20 \\
\hline Sell immediately after harvest & 37 & 49.33 \\
\hline
\end{tabular}

Table 10: Estimated amount of loss after harvest per $100 \mathrm{~kg}$

\begin{tabular}{|l|l|l|l|}
\hline Reason for the post-harvest loss & Frequency & Mean loss per 100 kg & Standard Deviation \\
\hline improper way of harvest & 8 & 13.63 & 6.55 \\
\hline lack of storage facility & 21 & 13.14 & 2.78 \\
\hline poor transportation & 35 & 17.11 & 2.94 \\
\hline insect pest attack & 11 & 14.36 & 2.38 \\
\hline Total & 75 & 15.22 & 3.77 \\
\hline
\end{tabular}

Table 11: Activities performed after harvesting of the fruit

\begin{tabular}{|l|l|l|}
\hline Activities & Frequency & Percent \\
\hline Grading & 46 & 61.3 \\
\hline Packing & 1 & 1.3 \\
\hline None & 28 & 37.3 \\
\hline Total & 75 & 100 \\
\hline
\end{tabular}




\section{Conclusion}

Citrus has been major fruit crop for Solukhumbu District. Their experience, practice is still insufficient to eradicate problems among value chain actors. Though the study area was highly potential, citrus were in unproductive state with a majority of farmers lacking technical knowledge on citrus farming.

Though there is the wide scope of commercialization, citrus not being in the priority of DADO and ineffectiveness of various practices, problems are prevailing in citrus farming in the area. Problems were categorized as input level problems, production problems and post-harvest and marketing problems. Input and production problems were further categorized into technical and management and socio-economic problems. The major technical problem in input was the unavailability of mechanical tools and the socio-economic problem was an economically poor condition of farmers as most of the respondents had agriculture as a major occupation with low income per year. Likewise, the major technical problem in production was insect pest attack and lack of record keeping in the farm. Similarly, the problem in post-harvest and marketing was poor transportation facility. In addition, ill effect of natural calamities, bad intercrop practices, lack of storage and marketing havocs in commodities each year. Services provided by Citrus Zone to farmers were satisfactory but most of the farmers did not have access to the services.

\section{Recommendations}

$>$ Technical knowledge is vital for the development of enterprises. So, technical information should be disseminated among farmers through scheduled training, observational visit and demonstration programs

$>$ Fertilizers, pesticides and mechanical tools and basic using concepts should be made accessible to the farmers

> Provision for loan, subsidy and incentives can encourage farmers towards commercialization

$>$ High yielding variety grafted with trifoliate rootstock should be provided

> Farmers should be assisted to strengthen value chain actors via policy development

$>$ Insurance policies, technologies to control insectsdiseases, storage should be made accessible to reduce unpredicted pre and postharvest loss.

\section{References}

DADO (2016) Annual Program and Statistics Booklet, F.Y. 2072/73. Solukhumbu: District Agriculture Development Office.

Gelal D (2018). Problems in Commercialization of Citrus in Solukhumbu District. (K. N. Pant, Interviewer)

MoAD (2016). Statistic Agriculture Book. Singh Durbar: Government of Nepal, Ministry of Agriculture Development, Monitoring Evaluation and Statistics Division, Agri Statistics Section.

MoAD (2017) Project Document of Prime Minister Agriculture Modernization Project. Ministry of Agriculture Development.

NCRP (2016) Annual Program and Statistics: An Overview. Kirtipur, Kathmandu: National Citrus Development Program.

Pun AA (2015). Citrus Farming Technology in Nepal. Dhankuta: National Citrus Research Programme 